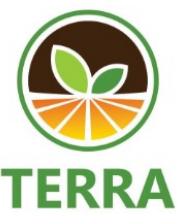

Journal of Land Restoration

\title{
Relationship Analysis of Soil Bulk Density, Available K, and Slope to Productivity of Salak Pondoh at Padang Jaya, North Bengkulu
}

\author{
Muhammad Yakub $^{1}$, M. Faiz Barchia ${ }^{2 *}$, Usman K.J. Suharjo $^{1}$ \\ ${ }^{1}$ Agroecotechnology Department, University of Bengkulu \\ ${ }^{2}$ Soil Science Department, University of Bengkulu (Corresponding author) \\ e-mail:faizbarchia@unib.ac.id
}

\begin{abstract}
Salak (Zalacca edulis Gaertn. Voss) is one of the most populair native fruits of Indonesia, consumed as a table fruit by most Indonesians. However, the yield of salak pondoh grown in Bengkulu is still lower than that in their native soil Java, believed to have more suitable soil properties for growing salak pondoh. The objective of this research were to evaluate the relationship of soil bulk density, available $K$, and slope to the productivity of salak pondoh grown at Padang Jaya Regency, North Bengkulu. We did a survey to collect data on soil bulk density (BD), available $K(K)$, and slope as well as the productivity of salak pondoh grown at Padang Jaya from November 2017 to May 2017. The results showed that there was a significant relationship between soil characteristics and salak productivity, as shown in a linear model of $Y=2.929-1.070 \mathrm{BD}+0.069 \mathrm{~K}-0.126$ Slope. Soil K was positively correlated to salak productivity, suggesting that salak productivity increased with an increase in soil K. On the other than, soil bulk density and slope were negatively correlelated to salak productivity, indicating that salak productity decreased with an increase in slope and in soil bulk density.
\end{abstract}

Keywords: salak pondoh, bulk density, K, Padang Jaya, slope

\section{INTRODUCTION}

Salak (Salacca zalacca Gaertn. Voss) is a plant from the Palmae family with edible fruit. Consumers generally like salak which has thick flesh, sweet taste, and small seeds. These criteria are met by the salak cultivars Pondoh, Nglumut, and Bali which are the 3 superior Indonesian salak cultivars apart from the varieties of Swaru, Enrekang, and Sugar (Daud, 2001). Zalacca is an exotic plant native to Indonesia with quite a lot of species diversity, there are at least 12 cultivars of salak that are cultivated by people from West Java, Central Java, and East Java (Nandariyah, 2007). Salak is one of Indonesia's native plants that are popular with the people, because it tastes sweet, delicious, and has a high nutritional value. Every $100 \mathrm{~g}$ of salak fruit contains 77 calories, $0.5 \mathrm{~g}$ protein, $20.9 \mathrm{~g}$ carbohydrates, $28 \mathrm{mg}$ calcium, $18 \mathrm{mg}$ phosphorus, $4.2 \mathrm{mg}$ iron, $0.04 \mathrm{mg}$ vitamin $\mathrm{B} 1$, and 2 $\mathrm{mg}$ vitamin $\mathrm{C}$ (Kusumo et al.., 1995). Zalacca production from year to year tends to be stagnant, but in 2011 there was an increase of 44.3 percent to 1.08 million tons compared to 2010. It was recorded that starting from 2007 to 2012 the production of bark was
$805879,862465,829,014,749,876,1,082,125$, and $1,035,407$ tons (Biro Pusat Statistik, 2014).

Salak pondoh can be developed in a generative and vegetative manner (Gustini, 2012). Generative cultivation of salak pondoh has the advantages, among others, that it can be done easily and cheaply, obtains a lot of seeds, the resulting plants grow healthier, the resulting plants have strong roots so they are resistant to falling, and the possibility of improving their properties in the form of crosses (Prihatman, 2000 ).

Salak (Salacca zalacca Gaertn. Voss) is a type of plant that can be used as a method of land conservation with a variety of cropping patterns. To conserve landslideprone areas, the cultivation of salak plants is an alternative because it has many advantages. Salak plants can be planted in the lowlands to the highlands of 50 800 above sea level on loose soil with a loamy sand structure with soil acidity $(\mathrm{pH}) 4-7.5$ and rainfall 200-400 mm per month. 70-80\% solar radiation, 80$90 \%$ high humidity and $20-30{ }^{\circ} \mathrm{C}$ temperature (Astuti, 2007).

The ideal air temperature for salak ranges from $20-30{ }^{\circ} \mathrm{C}$, if the temperature is too high or low it will affect the development of zalacca fruit and seeds. Soil moisture is very necessary for the growth of the 
roots of the salak plant. Zalacca plants do not want excessive soil moisture so that in the rainy season the planting land needs good drainage to prevent the plants from excessive puddles. Meanwhile, to ensure optimal growth in the dry season, the planting area requires sufficient soil moisture. Therefore, it is highly recommended that in the middle of the zalacca garden create ponds and ponds which are expected to maintain soil moisture.

Soil bulk density has no significant relationship with the yield of salak Pondoh. However, it can be seen that the higher the soil bulk density, the lower the salak Pondoh results. This is because the soil will become denser, which makes it difficult for plant roots to penetrate the soil so that the nutrients needed by plants are not fully absorbed by the plants. Soil bulk density is one of the physical properties of soil that is most often determined, because of its close association with ease of root penetration in the soil, soil drainage and aeration, and other physical properties (Grossman \& Reinsch, 2002). Soil bulk density diversity is highly dependent on the type of soil constituent fraction including soil texture (Suhardi, 1997). Soil bulk density is an indication of soil density, the denser the soil, the higher the soil bulk density, meaning that it is more difficult to pass water or be penetrated by plant roots. The factors that affect soil bulk density are the amount of pore space or soil porosity, the greater the soil porosity and the amount of porous space, the smaller the volume weight will be (Nurhidayati, 2006).

The slope is a factor that needs to be considered, starting from the preparation of agricultural land, planting efforts, taking products, and preserving the land. Land that has a slope can be more easily disturbed or damaged, especially if the degree of slope is large. Soil that has a slope of $>15 \%$ with high rainfall can cause landslides (Kartasapoetra, 1990). The steeper and longer the slope will increase the surface flow velocity and the larger surface water volume so that more objects can be transported (Martono, 2004). One of the efforts to reduce the level of erosion hazard on land slopes is by making terraces (Kartasapoetra et al., 1987).

To obtain high yield and quality of salak "Pondoh Super", it is necessary to take care of the plants. The addition of nutrients and thinning of the fruit are two things that are quite important as a determinant of the yield and quality of salak pondoh. One of the nutrients that plants need is potassium. The role of potassium is to help the formation of protein and carbohydrates and as an activator of various enzymes. Potassium is a cation that is indispensable in the process of photosynthate translocation in the phloem vessels (Marschner, 2003).

The existence of the zalacca garden belonging to the community has the potential to be developed because of the high market potential and the quality of the salak flavor produced is quite good (not inferior to products from other regions). Therefore, to support this development, information on the environmental characteristics of its growth is needed.

This study aims to determine the relationship between soil bulk density, available $\mathrm{K}$, and slope against the yield of salak pondoh in Padang Jaya District, North Bengkulu Regency.

\section{MATERIAL AND METHOD}

This research was conducted from December 2016 to March 2017 which took place in Padang Jaya Bengkulu Utara. The object observed was salak Pondoh with several stages of research. The pre-survey was conducted in the form of consultation as well as guidance with lecturers to determine the purpose of conducting research. There are several more stages carried out in the pre-survey such as observation, making a working map, field survey to determine the research location, and sample selection.

The selection of sample plants was carried out by purposive sampling with the categories of poor production, moderate production, good production, then fruit samples were taken from each plant to weigh fruit weight, fruit color, measure plant height, measure canopy length, and leaf width. The next stage is observing and analyzing the soil in the root zone of the plant. What was observed were soil texture, soil structure, slope, drainage, and $\mathrm{K}$ nutrients.

Soil sampling is done by taking three points around the plant and the soil taken at these three points is then compiled into one soil sample. The observed plant variables were fruit weight per bunch. Samples were taken in one plant, namely one bunch per plant, then counted the number of fruits per bunch, 3 salak fruit were taken from the sample bunch (large medium small) then weighed and averaged.

The data collected were analyzed using multiple regression with prediction models : $Y=a+b_{1} B D+$ $b_{2} K+b_{3}$ Slope

\section{RESULT AND DISCUSSION}

The observed research locations are locations that are by the observation parameters that have salak Pondoh plants, namely unit 1 , unit 2 , and unit 3 , which are the center of the salak pondoh plantation. The climatic conditions in Padang Jaya Subdistrict in the last 5 years have an average rainfall of $2546 \mathrm{~mm}$ year $^{-1}$ and an average rainy day of 170 rainy days. Geographically, Padang Jaya District is located at coordinates 10208'0 " - 1020-18'40 " East Longitude (EL) and $3^{\circ} 14^{\prime} 40 "-3^{\circ} 20$ 'South Latitude (SL). The area of Padang Jaya is 41,902.67 ha, with an area of $54.85 \mathrm{ha}$. The results of the descriptive analysis of the relationship between the physical properties of the soil and the results of the salak pondoh can be at 6 slope levels as shown in Table 1 and 2. 
Table 1. Physical and chemical properties of soil against the weight of salak Pondoh bunches

\begin{tabular}{|l|c|l|l|l|c|c|c|}
\hline Location & $\begin{array}{c}\text { Slope } \\
(\%)\end{array}$ & Drainage & Texture & Structure & $\begin{array}{c}\mathrm{BD} \\
\left(\mathrm{g} / \mathrm{cm}^{3}\right)\end{array}$ & $\begin{array}{c}\mathrm{K} \\
(\mathrm{ppm})\end{array}$ & $\begin{array}{c}\text { Yield fruit } \\
\text { bunch }(\mathrm{kg})\end{array}$ \\
\hline Unit 1 & 5 & Good & Loamy clay & Crumb & 1.02 & 1.72 & 10.381 \\
\hline Unit 1 & 8 & Good & Sandy clay & Crumb & 0.97 & 0.72 & 0.4107 \\
\hline Unit 1 & 12 & Good & Sandy clay & Crumb & 0.95 & 0.3 & 0.249 \\
\hline Unit 2 & 7 & Good & Sandy clay & Granular & 0.96 & 1.39 & 15.134 \\
\hline Unit 2 & 8 & Good & Sandy clay & Granular & 0.89 & 1.21 & 0.6984 \\
\hline Unit 2 & 7 & Poor & Loamy clay & Crumb & 1.51 & 0.74 & 0.486 \\
\hline Unit 3 & 6 & Good & Loamy clay & Crumb & 0.85 & 1.23 & 20.128 \\
\hline Unit 3 & 11 & Medium & Loamy clay & Crumb & 1.26 & 0.47 & 0.75 \\
\hline Unit 3 & 8 & Medium & Loamy clay & Crumb & 1.35 & 1.08 & 0.331 \\
\hline
\end{tabular}

Source: Data analyst at the soil science laboratory, Faculty of Agriculture, Bengkulu University

Table 2. Multiple regression of the physical and chemical properties of soil on the yield of salak Pondoh

\begin{tabular}{c|c|c|r|r|r}
\hline Variable & B & Std. Error & \multirow{2}{*}{ Beta } & \multicolumn{1}{c}{ T } & Significancy \\
\hline BD & -1.070 & 2.854 & -0.416 & -1.169 & 0.295 \\
\hline K & 0.069 & 0.915 & 0.054 & 0.075 & 0.943 \\
\hline Slope & -0.126 & 0.925 & -0.047 & -0.688 & 0.522 \\
\hline Constant & 2.292 & 0.182 & & 1.026 & 0.352 \\
\hline
\end{tabular}

The results of the regression analysis on the independent and dependent variables resulted in an estimation model of $\mathrm{Y}=2.929-1.070 \mathrm{BD}+0.069 \mathrm{~K}$ - 0.126 Slope with a value of R2 $=0.49$. However, the variables of soil physical and chemical properties partially or simultaneously have no significant effect on the production of salak Pondoh.

Potassium has a positive relationship with the results of salak Pondoh. This means that the higher the $\mathrm{K}$ content, the salak Pondoh results will increase. Research by Nurrochman et al. (2011) showed that the highest production of salak pondoh was found in salak plants which were fertilized with fertilizers containing $\mathrm{K}$. According to Marschner (1997), potassium can help form protein and carbohydrates as well as an activator of various enzymes. The $\mathrm{K}$ element is a cation that is indispensable in the process of photosynthate translocation in the phloem vessels so that the fruit formation process will be faster and better. Likewise with the statement of Ainzworth \& Bush (2011), that the increase in the reserves of supporting components will be followed by an increase in photosynthesis and translocation to the storage organ, in this case, the salak fruit.

The availability of $\mathrm{K}$ for plants depends on soil aspects and climatic parameters which include: the amount and type of clay minerals, CEC, buffering capacity, humidity, temperature, aeration, and soil $\mathrm{pH}$ (Havlin et al., 1999). In addition to soil and climate 
factors, plant species and varieties also affect $\mathrm{K}$ uptake, where tolerant plants require small amounts of $\mathrm{K}$ and on the other hand sensitive plants require large amounts of $\mathrm{K}$. One of the mechanisms for plant tolerance to nutrient deficiencies is by removing organic acid exudates around the roots (rhizosphere). Furthermore, organic acids can dissolve nutrients $(\mathrm{P}$, $\mathrm{K}, \mathrm{Fe}, \mathrm{Mn}$, etc.) that were not previously available to become available for plants (Marschner, 1997). Various studies by Zhu \& Luo (1993) show that organic acids and several cations ( $\mathrm{NH} 4+, \mathrm{Na}+$, etc.) have a very important role in increasing soil $\mathrm{K}$ availability. Some cations such as $\mathrm{Ca} 2+$ and $\mathrm{Na}+$ can replace the $\mathrm{K}$ position in the mineral structure of muscovite due to weathering (Shidu, 1987). Also, NH4 + and K + can compete in locating the absorption complex in the inner position of the space between clay mineral layers type 2: 1 (Evangelou \& Lumbanraja, 2002; Kilic et al., 1999).

The slope has a negative relationship with the results of salak Pondoh. This means that the higher the slope of the land, the salak Pondoh results will decrease. The slope is a factor that needs to be considered since the preparation of agricultural land and its planting efforts. Land that has a slope $>15 \%$ can be easily disturbed or damaged, especially if the slope is large.

Soil that has a slope of $>15 \%$ with high rainfall can cause landslides (Kartasapoetra, 1990). One of the efforts to reduce the level of erosion hazard on land slopes is by making terraces (Kartasapoetra et al, 1987). From the criteria for a good slope class of salak Pondoh that is $<8 \%$ (Djaenudin 2011), according to the results of the study, with a slope of $5 \%$ to $7 \%$, the yield is higher.

Soil bulk density has no significant negative relationship with the results of salak Pondoh. This means that the higher the soil bulk density, the salak Pondoh results will decrease. Soil density will make it difficult for plant roots to penetrate the soil so that the nutrients needed by plants are not fully absorbed by the plants. Soil bulk density is one of the physical properties of soil that is most often determined, because of its close association with ease of root penetration in the soil, soil drainage and aeration, and other physical properties (Grossman \& Reinsch, 2002). Soil bulk density diversity is highly dependent on the type of soil constituent fraction including soil texture (Suhardi, 1997). Soil bulk density is an indication of soil density, the denser the soil, the higher the volume weight, meaning that it is more difficult to pass water or be penetrated by plant roots. The factors that affect soil bulk density are the amount of pore space or soil porosity, the greater the soil porosity and the amount of porous space, the smaller the volume weight will be (Nurhidayati, 2006).

Drainage is a way of collecting and disposing of water from the ground (Hakim et al., 1986). In the re- search area, there are three classes of drainage, which are categorized as good, medium, and bad. Drainage can also help the surface of the land to absorb the density of water into the soil (infiltration), and help process water flowing in the soil which causes air exchange between the soil grains and the atmosphere which results in increased oxygen $(\mathrm{O} 2)$ levels in the root zone and reduced carbon dioxide ( $\mathrm{CO} 2)$ in soil particles. High $\mathrm{O} 2$ concentrations in the soil can affect plant growth rates. By Efendy's (2011) statement, good drainage can also affect soil moisture, which at sufficient levels will affect plant growth rates.

Good drainage can help the physical properties of the soil, because it will be related to one another, both in terms of soil texture, soil structure, and soil volume weight. Good drainage will be directly related to the physical properties of the soil, namely the porosity of the soil which can help the soil infiltration rate.

Apart from the availability of $\mathrm{K}$, soil bulk density, and slope, thinning the fruit is also a factor affecting the production of salak Pondoh. Fruit thinning by $10 \%$ of fruit in one bunch gave the highest fruit and bunch weight not different from other treatments except for fruit thinning of $30 \%$. Increasing thinning of fruit to $30 \%$ of fruit in one bunch significantly increased the weight per fruit (Nurrochman et al., 2011).

\section{CONSCLUSION}

The results showed that there was a nonsignificant relationship between soil characteristics and salak productivity, as shown in a linear model of $\mathrm{Y}=2.929$ -1.070 BD + 0.069 K - 0.126 Slope. Soil K was positively correlated to salak productivity, suggesting that salak productivity increased with an increase in soil K. On the other than, soil bulk density and slope were negatively correlated to salak productivity, indicating that salak productivity decreased with an increase in slope and soil bulk density.

\section{References}

Ainzworth, E.A. \& Bush, D.R. (2011). Carbohydrate Export from the Leaf: A Highly Regulated Process and Target to Enhance Photosynthesis and Productivity. American Society of Plant Biologists.

Astuti. (2007). Budidaya Salak. Agromedia Pustaka. Jakarta. Badan Pusat Statistik. (2014). Statistik Pertanian. Badan Pusat Statistik, Jakarta.

Daud, I. (2001). Salak, palem berduri asli anak negeri.www.indomedia.com/intisari/salakpalem. [20 Februari 2016]. 
Djaenuddin, D, Marwan, H., Mulyani, A. \&Suharta, N, (2000). Kriteria Kesesuaian Lahan untuk Komoditas Pertanian. Departemen Pertanian. Direktorat Jenderal Tanaman Pangan, Jakarta.

Djaenuddin D. (1997). Buku Penyusunan Kriteria Kesesuaian Lahan untuk Komoditas Pertanian, Pusat Penelitian Tanah dan Agroklimat, Badan Penelitian dan Pengembangan Pertanian, Bogor.

Effendy. (2011). Drainase untuk meningkatkan kesuburan lahan rawa. Jurnal Teknik Sipil, 6(2), 39-44.

Evangelou, V.P. \& Lumbanraja, J. (2002). Ammoniumpotassium-calcium exchange on vermiculite and hydroxy-aluminumvermiculite. SSSAJ, 66, 445-455.

Gustini, D., Fatonah, S. \& Sujarwati. (2012). Pengaruh Rootone F dan pupuk Bayfolan terhadap pemben -tukan akar dan pertumbuhan anakan salak Pondoh (Salacca edulis Reinw). Biospecies, 5 (1), 8-13.

Grossman, R.B.T. \& Reionsc. (2002). The solid phase. p. 201-228. In J. H. Dane and G. C. Topp (Eds). Methods of Soil Analysis, Part 4Physical Methods. Soil Sci. Soc. Amer., Inc. Madison Wisconsin.

Hakim, N., Lubis, A.M., Nugroho, S.G., Diha, M.A., Hong, G.B. \& Bailey, H.H. (1986). Dasardasar Ilmu Tanah. Universitas Lampung, Bandar Lampung.

Hardjowigeno, S. (2003). Klasifikasi Tanah dan Pedogenesis. Penerbit Akademika Presindo, Jakarta.

Havlin, J.L., Beaton, J.D., Tisdale, S.L. \& Nelson, W.L. (1999). Soil Fertility and Fertilizers.An Introduction to Nutrient Management. Sixth Edition. Prentice-Hall. Upper saddle river, New Jersey.
Kartsapoetra, A. G. (1990). Kerusakan Tanah Pertanian dan Usaha Untuk Merehabilitasinya. Bina Aksara, Jakarta.

Kartsapoetra, G., Kartasapoetra, A.G. \& Sutedjo, M.M. (1987). Teknologi Konservasi Tanah dan Air. Bina Aksara, Jakarta.

Marschner, H. (1997). Mineral Nutrition of Higher Plants. Second Edition. Academic Press, Harcourt Brace \& Company, Publisher, Tokyo.

Nurhidayati. (2006). Bahan Ajar Dasar-dasar Ilmu Tanah. Fakultas Pertanian UNISMA, Malang.

Nandariyah. (2007). Kajian Keragaman Kultivar Salak Jawa Berdasarkan Penanda Morfologi dan RAPD. Disertasi. Sekolah Pasca Sarjana. Universitas Gadjah Mada, Yogyakarta.

Nurrochman, Trisnowati,S., \& Muhartini, S. (2011). Pengaruh Pupuk Kalium Klorida dan Umur Penjaranagan Buah terhadap hasil dan Mutu Salak (Salacca zalacca (Gaertn.) Voss) Pondoh Super

Prihatman, K. (2000). Salak Pondoh. http//: waritek. ristek.go.id/pertanian/salak pondoh.pdf. [02 Februari 2016].

Pane, J. (2003). Pengaruh penjarangan buah terhadap hasil salak kulitvar Pondoh dan lokal Sleman, Skripsi. Fakultas Pertanian, Universitas Gadjah Mada, Yogyakarta.

Santoso, H.B.(1993). Salak Pondoh. Kanisius, Yogyakarta.

Sidhu, P.S. (1987). Mineralogy of potassium in soils of Punjab, Haryana, Mimachal Pradesh and Jammu and Kashmir. Potash Review No.6/1987. International Potash Institute, Switzerland.

Yong-Guan, Z. \& Jia-Xian, L. (1993). Release of non-exchangeable soil $\mathrm{K}$ byorganic acids. Pedosphere ,3, 269-276. 